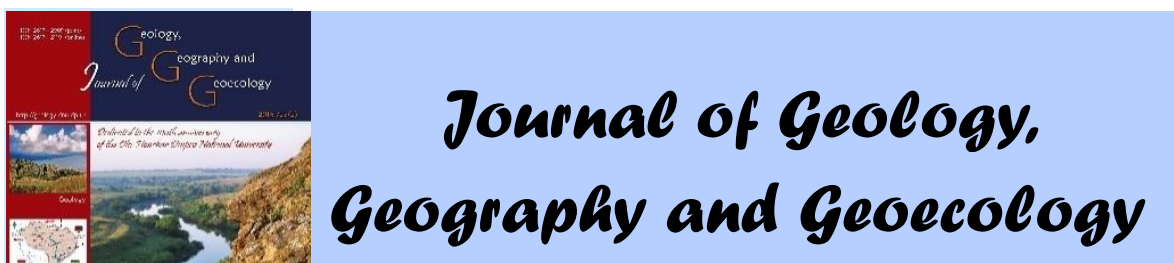

Journal home page: geology-dnu-dp.ua

Journ.Geol.Geograph. Geoecology, 28(1), 51-58

doi: $10.15421 / 111906$

N. Gerasimenko, T. Yurchenko, Ye. Rohozin

Journ.Geol.Geograph.Geoecology, 28(1), 51-58

\title{
Vegetation changes in the Hotyn Upland over the last 2000 years (based on pollen data)
}

\author{
N. Gerasimenko, T. Yurchenko, Ye. Rohozin
}

Taras Shevchenko National University of Kyiv, Ukraine, e-mail: n.garnet2@gmail.com

Received 10.12.2018;

Received in revised form 28.12.2018;

Accepted 05.01.2018

taken from the soils of different ecotops in the sites' vicinity. The reconstructed short-period phases of environmental change correspond well with those established in other areas. These are the end of the "Roman warm period" (before the ${ }^{14} \mathrm{C}$ date of $1.74 \mathrm{ka}$ $\mathrm{BP}$ ), with the humid climate; the relatively dry "Dark Ages cool period" (before the ${ }^{14} \mathrm{C}$ date of $1.19 \mathrm{ka} \mathrm{BP}$ ); the wet "Medieval warm period"; the cool "Little Ice Age" (with its wetter beginning and drier ending) and the modern warm phase (the last 150 years). Centennial environmental changes - the cooling within the Medieval Warming (XI cent.) and the warming within the "Little Ice Age" (XV cent.) - have been detected. Human impact on the vegetation can be demonstrated - forest clearance (with the presence of particles of microscopic charcoal and pollen of pyrophitic plants), the introduction of thermophilous walnut during warm periods, and the appearance of pasture lands in the place of former fern patches and woods during the "Little Ice Age", and the last warm phase (with the presence of pollen of pastoral synanthropic plants). In the last 2000 years, broad-leaved woodland, dominated by hornbeam, grew extensively near Sadgora and Ridkivtsi only during the "Medieval Warm Period".

Keywords: palynology, different types of soil, short-period environment phases, human impact

\section{Зміни рослинності Хотинської височини впродовж останніх 2000 років (за палінологічними даними)}

Н. Герасименко, Т. Юрченко, С. Рогозін

Київський національний університет імені Тараса Шевченка, е-таil: n.garnet2@gmail.com

Анотація. На основі палінологічного аналізу двох грунтових розрізів, розташованих у різних умовах рельєфу i представлених різними грунтовими відмінами, простежено зміни рослинного покриву центральної частини Буковини впродовж останніх 2 тис. років (друга половина ранньої, середня та пізня субатлантика). Реконструкції давньої рослинності базуються на результатах вивчення поверхневих пилкових проб сучасних грунтів, відібраних у різних природних біоценозах району дослідження. Отримані дані добре зіставляються між собою та із паліноматеріалами із долини верхнього Дністра i відображають короткоперіодичну етапність розвитку рослинності як індикатора кліматичних змін, а також й антропогенний вплив на рослинний покрив. Простежено закінчення фази теплого і вологого клімату першої половини ранньої субатлантики (до ${ }^{14} \mathrm{C} 1740$ років тому), прохолодну і відносно посушливу (на межиріччях) фазу середньої субатлантики (до ${ }^{14} \mathrm{C} 1190$ років тому), «Кліматичний оптимум середніх віків» (X-XII ст.), «Малий льодовиковий період» (XIII-XIX ст.) i сучасну теплу фазу (від 150 років тому). Короткострокові підфази похолодання впродовж оптимуму середніх віків (XI ст.) i потепління впродовж «Малого льодовикового періоду» (XV ст.) зіставляються із аналогічними кліматичними подіями у Європі. Вплив людини на рослинність виявлено за ознаками випалювання лісів (збагачення грунтів частками мікроскопічного вугілля, наявність пилку рослин-пірофілів), інтродукцією горіха волоського на фазах потеплінь, а впродовж останніх століть - за появою пилку пасовищних синантропних рослин на місці зведених лісів і папоротевих угруповань. Широколисті ліси востанне зростали на досліджених територіях впродовж «Кліматичного оптимуму середніх віків».

Ключові слова: палінологія, різногенентичні трунтові відміни, короткоперіодична палеогеографічна етапність, антропогенний вплив. 
Introduction. In the last decade, with the concern about future climate change, the study of climatic variability over the last two millennia has become a particular research focus. Patterns of temperature variability that were similar across the northern hemisphere have been demonstrated (Christiansen, 2012). The important task is to reveal how different ecosystems and their particularly sensitive component - vegetation, responded to climate change on the scale of few centuries. Pollen data are a reliable proxy for vegetational reconstruction of the past. A comparison of regional pollen results with general trends enables us to detect past human impacts on vegetation, and to relate it to natural climatic and environmental variability. The Bukovyna remains one of the least studied areas for these topics. The aim of this study is to reveal changes in vegetation in the Bukovyna founded on palynological analyses of different soil types, and to assess human impact on the vegetation cover over the last two millennia.

In the northern Dniester basin, C. Kremenetski (Huhmann et al., 2004) showed that from the Middle Subatlantic (after $1.6 \mathrm{ka} \mathrm{BP}$ ) human activity caused a decline in mesophilic broad-leaved trees, which, from the Late Subatlantic (after $0.8 \mathrm{ka} \mathrm{BP}$ ), was followed by a marked expansion of forbs and synanthropic vegetation. N. Kalynovych $(2003$, 2004) proved that a phase of oak, hornbeam and beach $(2.0 \mathrm{ka}$ BP) was replaced by the phase of birch (1.9 - $0.6 \mathrm{ka}$ BP) - distinctly indicating the clearance of primary woods. N. Chumak (2012) reconstructed this variability in the vegetation composition: around $1.7 \mathrm{ka}$ BP, broad-leaved trees did not play a significant role in the woodland which dominated the landscape (during a cool phase), but, later on, the maximum spread of Fagus took place that is correlated with the Medieval Warm Period (1.1-0.8 ka BP). During the Late Subatlantic (after $0.8 \mathrm{ka}$ $\mathrm{BP})$, a profound reduction in woodland occurred accompanied by the 'explosive' spread of ferns, indicating forest clearance. In the Bukovyna area, the first Holocene pollen record was described by O. Artyushenko et al. (1982) from floodplain deposits (the Onut site). The Late Holocene was distinguished by an increase in Abies, Picea and Fagus pollen (no dating was provided). According to pollen data from the deposits of the Bukovynka Cave (Gerasimenko et al., 2018), the culmination of the broad-leaved flora (particularly Carpinus) during the Subatlantic occurred in the Roman (2.2$1.8 \mathrm{ka} \mathrm{BP})$ and Medieval (1.0 ka BP) Warm Periods. Forest clearance increased after each of these warm phases, with the strongest reduction of broad-leaved taxa occurring during the "Little
Glacial Age". The cultivation of Cerealia started from $2.8 \mathrm{ka}$ BP.

Material and methods. Pollen study of two soils, located in different relief positions near the Chernivtsi has been carried out on ecotops undisturbed by human activity. The studied sites area is located on the southern slopes of the Hotyn Upland, in Eastern European broad-leaved geobotanical province, which natural vegetation shows a predominance of oak-hornbeam forest (Barbarych, 1977). Farther to the west, beech forest, and fir and spruce patches occur. The ground cover is dominated by forbs and grasses. Descriptions of soil profiles and ${ }^{14} \mathrm{C}$ dates have been provided by Y. Dmytruk (2015). The Sadgora 1 site $\left(48^{\circ} 20^{\prime} 58^{\prime \prime} \mathrm{N}, 25^{\circ} 59^{\prime} 24^{\prime \prime} \mathrm{E}\right)$ is located at the bottom of a gully, covered by herbs, and it shows a soil succession ( $2.15 \mathrm{~m}$ thick) of three calcaric gleyic Fluvisols, each with similar genetic profiles, with Hk, Hpk and PhkGl horizons. The Ridkivtsi 1 section $\left(48^{\circ} 21^{\prime} 51^{\prime}\right.$ ' $\mathrm{N}, 26^{\circ} 01^{\prime} 24^{\prime}$ ' $\mathrm{E}$ ) is located on a gentle slope and shows a Luvic Greyzemic Phaeozem (1.42 $\mathrm{m}$ thick) with these genetic horizons: Hd, H(e), Eh, Ie(h)gl, I(gl), Pikgl. The modern vegetation is herbaceous.

Pollen samples were collected from each soil horizon at $10 \mathrm{~cm}$ intervals (22 samples from the Sadgora 1 site and 14 samples from the Ridkivtsi 1 site). The samples were processed following this method: boiling in a $10 \%$ solution of $\mathrm{HCl}$ to dissolve carbonates, disaggregation in a $15 \%$ solution of $\mathrm{Na}_{4} \mathrm{P}_{2} \mathrm{O}_{7}$ in order to remove clay particles, removal of the secondary carbonates with $\mathrm{HCl}$, boiling in a $10 \%$ solution of $\mathrm{KOH}$ to dissolve organic matter, treatment in a heavy liquid $\left(\mathrm{CdI}_{2}\right.$ and $\mathrm{KI}$, specific gravity 2.0 ) in order to separate palynomorphs from silt particles, treatment with a $40 \%$ solution of cold HF in order to dissolve quarts. All samples show very good preservation of palynomorphs. At least 200 pollen grains were counted in the majority of the samples. Nevertheless, the samples from the $\mathrm{I}(\mathrm{gl})$ and Pikgl soil horizons from Ridkivtsi 1 section contained only a few pollen grains per slide and, thus, were not used in the vegetational reconstructions. Pollen grains were identified with the aid of pollen atlases (Kupriyanova, Alyeshina, 1972, 1978; Reille, 1995, 1998) and the reference pollen collection of the Geography Faculty of the Taras Shevchenko National University of Kyiv. The program C2 was used to plot the pollen diagrams. These abbreviations are used in this paper: $\mathrm{AP}$ - pollen of trees and shrubs, NAP - pollen of herbs, grasses and sedges, PZ - pollen zone, NPP - non-pollen palynomorphs, which in the studied sections included Pseudoschizaea circula and Glomus-type spores. The former is an indicator of ground 
moisture, the latter shows a substrate rich in nutritious materials. Filicales spores in the sediments studied are mainly represented by Polypodiaceae.

The reconstructions of past vegetation dynamics are based on the methodological principles elaborated by V. Grichuk (1989) and N. Bolikhovskaya (1995). In order to check the correspondence between the modern composition of vegetation and its representation in the surface pollen samples, 10 samples have been taken from the surface of the soils around the studied site. One sample was taken at the each of the two sites, and the rest were collected from the surroundings under the canopies of different types of woodland, at the edge of forests and in the meadow. The obtained surface samples represent well the general type of vegetation, but in the samples, collected in the forest, some broad-leaved species are underrepresented (with exception of Carpinus betulus and Fagus sylvatica in beach-hornbeam forest). A common inconsistency between the surface samples and the modern vegetation is the overrepresentation of pine pollen - up to $40-60 \%$ at open landscapes, though 10-20\% where under a broad-leaved canopy.

Results. 1. Pollen from the Sadgora 1 section (Fig. 1, from the bottom to top). PZ S-1 (2.1-1.8 m, the lower part of the PhkGl horizon of the lower soil) shows spectra of a forest type (AP 59-67\%, spores $30-38 \%$ and NAP 3-4\%). The last includes forbs. Pinus sylvestris (53-63\%) is most abundant in the AP, whereas Picea (3-5\%) and broad-leaved trees $(1-3 \%$ in total) is infrequent. Thermophilous taxa include Fagus (1-3\%), Quercus and Carpinus ( $<1 \%$ of each). Filicales dominate the spores (27-29\%), whereas Sphagnum and Lycopodiales each constitute 1-5\%. Glomus-type spores are frequent $(12-15 \%)$.

In PZ S-2 (1.8-1.65 m, the upper part of the PhkGl horizon), AP also predominates (53-59\%), spores are abundant $(37-43 \%)$ and NAP occurs rarely $(4 \%)$. Percentages of Pinus sylvestris decrease $(42-53 \%)$ balanced by some increase in Picea pollen (5-9\%), with only a few grains of Fagus occurring. Percentages of spores increase due to the abundance of Filicales (29-36\%). Glomus-type spores are as frequent as before

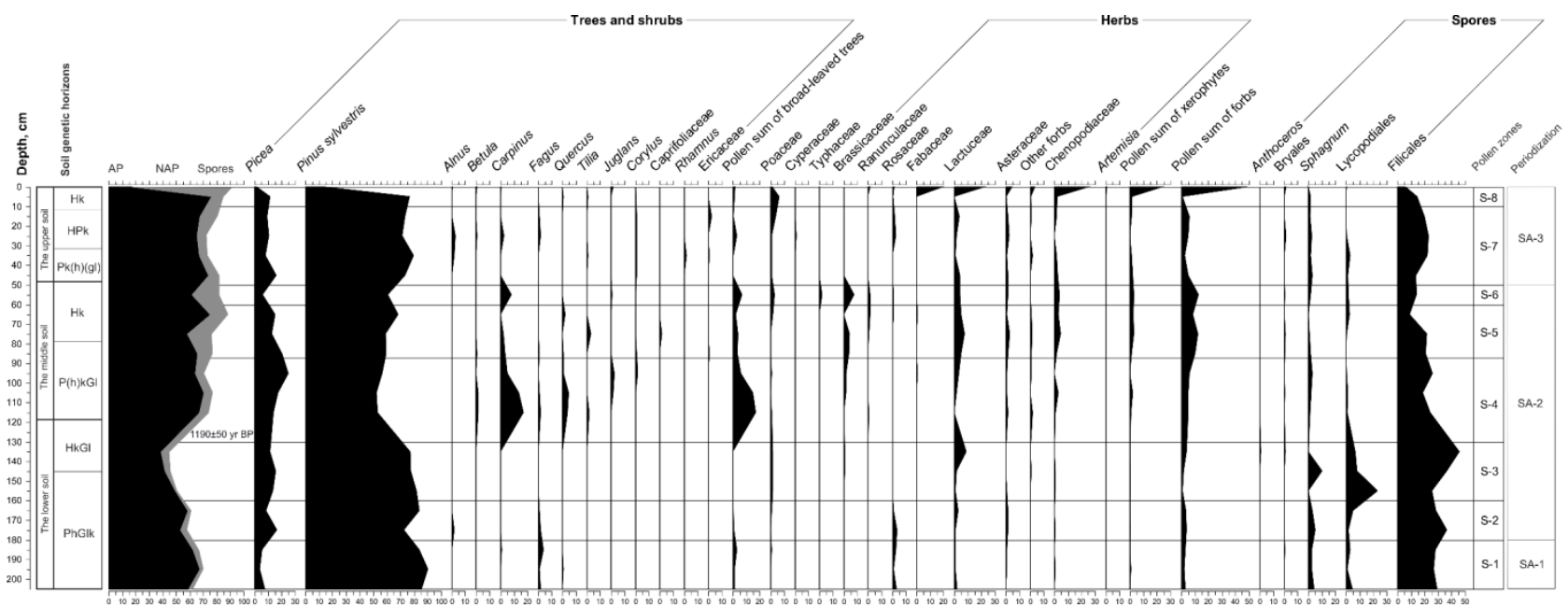

Fig. 1. Pollen diagram from the Sadgora 1 section.

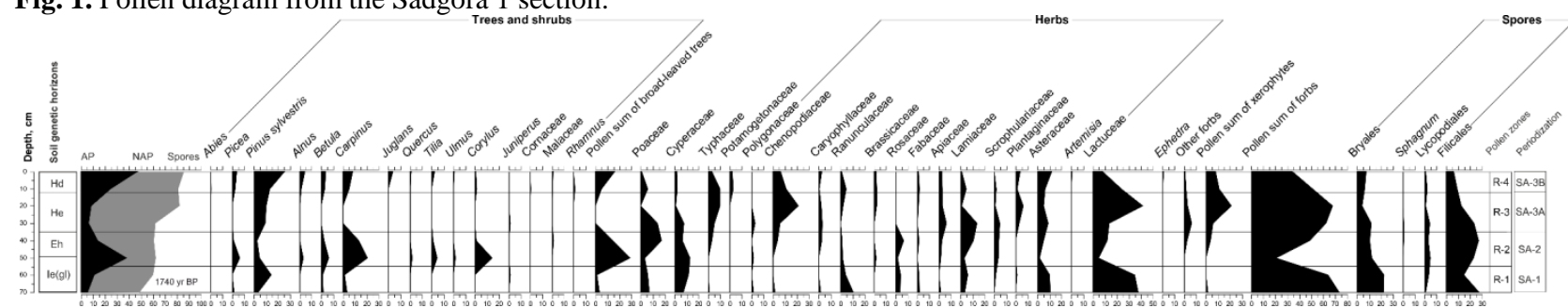

Fig. 2. Pollen diagram from the Ridkivtsi 1 section.

PZ S-3 (1.65-1.18 m, the HkGl horizon of the lower soil) is marked by a further increase in spores (49-56\%). AP constitutes 38-49\%, and NAP is only $3-6 \%$. The pollen composition is similar to that in PZ S-2. The spores are dominated by Filicales (25-48\%), though Lycopodiales (7-23\%) and Sphagnum (10\%) became rather frequent, and
Anthoceros laevis (an indicator of soil moisture) occurs. The spores of the microalga Pseudoschizaea circula became noticeable (2-5\%), also pointing to excess ground moisture, and Glomus-type spores are still frequent.

PZ S-4 (1.2-1.0 m, the lower part of the $\mathrm{P}(\mathrm{h}) \mathrm{kGl}$ horizon of the middle soil) has a forest 
type of pollen spectra (AP 68-70\%, NAP 5-6\%, spores 24-27\%). Percentages of Pinus pollen became $\leq 40 \%$ with the corresponding increase in percentages (16-18\% in the sum) and diversity of pollen of broad-leaved trees: Carpinus (10-12\%), Quercus (3-4\%), Fagus, Tilia and Juglans $(\leq 1.5 \%$ of each). NAP mainly consists of diverse forbs. Spores are dominated by Filicales (20-25\%), while Sphagnum, Lycopodiales and Bryales each constitute $\leq 2 \%$, and Pseudoschizaea circula spores constitute 3-4\%, whereas Glomus-type spores fall in numbers (only 1-4\%).

PZ S-5 (1.0-0.8 m, the upper part of the $\mathrm{P}(\mathrm{h}) \mathrm{kGl}$ horizon of the middle soil) shows some increase in NAP (6-16\%), with AP being 59-76\%, and spores $24-30 \%$. Pinus sylvestris predominates in the AP (40-60\%), pollen of Picea reaches its maximum $(9-18 \%)$ in the diagram, whereas the sum of broad-leaved taxa pollen decreases (2-6\%): with Carpinus (at 2-4\%), Tilia, Juglans, Quercus, Corylus and Fagus (each at $\leq 2 \%$ ). The NAP is dominated by diverse forbs $(5-13 \%)$. The composition of spores and NPP is very similar to the PZ S-4.

PZ S-6 (0.8-0.5 m, the Hk horizon of the middle soil,) differs from PZ S-5 in showing a decrease in spore percentages (19\%), and in Picea pollen (5\%) and a further increase in NAP (20\%). The pollen of broad-leaved taxa include Carpinus (7\%) and Juglans $(0.6 \%)$. In the NAP, forbs remain dominant, but Poaceae, Typhaceae and Chenopodiaceae became noticeable (2-3\% of each). The spores consist of Filicales (14\%), Lycopodiales and Sphagnum (2\% of each). The disappearance of gley features in the soil coincides with a decline in the spores of Pseudoschizaea circula $(<2 \%)$. A slight increase in Glomus-type spores occurs (6$7 \%)$.

PZ S-7 (0.5-0.1 m, the Phk and Hpk horizons of the upper soil) has pollen spectra of a typical forest type (AP 65-76\%, NAP 4-10\%, spores 1628\%). Pinus sylvestris dominates the AP (51-65\%), Picea pollen is second in abundance (6-13\%), and only few grains of broad-leaved taxa are present (Carpinus, Fagus, Quercus, Tilia and Corylus (in the total $\leq 3 \%$ ). Palynomorphs of Alnus, Betula and Ericaceae became noticeable ( $<2 \%$ of each). NAP includes forbs, particularly Lactuceae, $\leq 4 \%$, with Poaceae (1-5\%), Chenopodiaceae and Cyperaceae $(\leq 2 \%)$. The composition of spores is similar to that in PZ S-6. Pseudoschizaea circula spores constitute $\leq 3 \%$, which indicates only periodical waterlogging in these horizons, and the number of Glomus-type spores is small (1-4\%).

PZ S-8 (0.1-0 m, the Hk horizon of the upper soil) has pollen spectra of meadow-steppe type (AP $18 \%$, NAP $75 \%$, spores $8 \%$ ). The AP includes
Pinus sylvestris (13\%), Picea (2\%), Juglans and Carpinus (each $<2 \%$ ). The NAP is dominated by forbs (49\%), which consist mainly of Lactuceae $(21 \%)$ and Fabaceae (18\%). Pollen percentages of xerophytes increase markedly - Chenopodiaceae (23\%) and Artemisia (1\%). Infrequent spores are represented by Filicales (4\%), Bryales and Lycopodiaceae (each <2\%). No spores of Pseudoschizaea circula were found, and Glomustype spores are not abundant (4-5\%).

2. Pollen from the Ridkivtsi 1 section. (Fig. 2, from the bottom to top) PZ R-1 (69-49 cm, the Ie(gl) soil horizon) has a meadow type of pollen spectra (AP $5-11 \%$, NAP $45-48 \%$, and spores $41-50 \%$ ). Pinus sylvestris dominates the AP (2-9\%), with Picea, Juniperus and Carpinus pollen present $(\leq 2 \%$ of each). The NAP consists of diverse forbs (36-38\%), particularly Lactuceae (18-21\%), with Cyperaceae (4-7\%) and Poaceae (3-4\%). Spores are dominated by Filicales (6-26\%), Bryales (21-22\%), with Lycopodiaceae (1-3\%) occurring infrequently. The samples include a lot of microcharcoal particles and $\leq 5$ of Glomus-type spores.

PZ R-2 (49-35 cm, the Eh horizon) has a forest-meadow pollen spectra (AP 38\%, NAP 22\%, spores $40 \%)$. The AP is dominated by broad-leaved taxa (26\%): with Carpinus (12\%), Corylus (9\%), Tilia (3\%), Ulmus and Quercus (1\% of each). Pollen percentages of Picea, Pinus sylvestris, Alnus and Betula are very low (2-4\%). Very diverse forbs dominate (12\%) the NAP, and Cyperaceae pollen is second in abundance (8\%). Spores include Filicales (23\%), Bryales (12\%), and rarely Lycopodiales (5\%). Only Pseudoschizaea circula is present, and the count of microcharcoal particles decreases noticeably.

PZ R-3 (35-12 cm, the H(e) horizon). This pollen zone has a meadow-steppe spectra (AP 6$14 \%$, NAP $46-55 \%$, and spores $39-41 \%$ ). The AP comprises Carpinus (up to 8\%), Pinus sylvestris (2$5 \%$ ), Picea, Betula, Juniperus, Tilia ( $<2 \%$ of each) and a few pollen grains of Corylus and Malaceae. Pollen of diverse forbs (from 15 families) dominates the NAP (28-35\%), Poaceae increases in abundance (8-10\%), and Chenopodiaceae, Cyperaceae and Typhaceae each $\leq 4 \%$. The spores include Filicales (23-26\%), Bryales (11\%), Lycopodiales (3-4\%) and Sphagnum $(<1 \%)$. Microcharcoal particles occur, but NPP are infrequent.

PZ R-4 (12-0 cm, the Hd horizon) has pollen spectra of a mesophytic steppe (AP 8-23\%, NAP 60-76\%, spores 16-17\%). The AP consists of Pinus sylvestris (8-10\%), Carpinus (4\%), Picea, Abies, Juniperus, Betula and Alnus ( $<2 \%)$. A few pollen grains reveal the presence of bushes of Corylus, Rhamnaceae, Cornaceae and Malaceae. The 
diversity of forbs, which dominate the NAP (40$52 \%$ ), remains high, though the Lactuceae is most abundant (18-32\%). Percentages of xeric Chenopodiaceae increase $(8-16 \%)$, whereas Poaceae and Cyperaceae $(<4 \%)$ are infrequent, and pollen of hydrophytes appears - Typhaceae (4-8\%) and Potamogetonaceae (1\%). Spores include Filicales, Polypodiaceae and Bryales (4-8\% of each) and Lycopodiales (1-2\%). The microcharcoal particles are rare, but the increase in Glomus-type spores in noteworthy (7-10\%).

Discussion. The differences apparent in the two soil profiles and their pollen successions were the result of their different positions in the relief. The Sadgora 1 site is situated at a gully bottom where there was continuous accretion of sediments, which, in its turn, led to the development of a succession from three individual soils $(>2 \mathrm{~m}$ in thickness), enriched in palynomorphs. The position of the Ridkivtsi 1 site on the upper part of the slope led to the formation of only one (1 m thick) soil. Translocation processes, which are typical for Luvic Phaeozem, controlled the development of its $\mathrm{I}(\mathrm{gl})$ horizon in hillwash deposits (derived from a sandstone parent rock), and this accounts for it being very poor in palynomorphs. According to the pollen data (PZ R-1), the $\mathrm{Ie}(\mathrm{h})(\mathrm{gl})$ soil horizon was formed in an open landscapes, that was dominated by forbs, ferns and green mosses. The ${ }^{14} \mathrm{C}$-date of $1.74 \mathrm{ka} \mathrm{BP}$, derived from this horizon, corresponds to a cool phase between $1.7 \mathrm{ka}$ and $1.4 \mathrm{ka} \mathrm{BP}$ (Bezusko et al., 1988; Chumak, 2012), known in Europe as the "Dark Ages cool period". This phase (IV cent. AD) also coincides with the "Migration Period", an arid time when the steppe belt of Ukraine was very dry (Gerasimenko, 2007). In the belt of broad-leaved forest, where the studied site is located, this aridity was not so dramatic, and meadow coenoses spread. The impact of forest clearance also cannot be excluded as a contributor to meadow expansion - microcharcoal particles occur, and Lactuceae pollen - one of the pioneer elements of herbal cover - dominates the NAP.

At Sadgora 1, judging from the sedimentation rates, the older soil was formed immediately before $1.19 \mathrm{ka} \mathrm{BP}\left({ }^{14} \mathrm{C}\right.$ date from the top of its Hk horizon). The lowermost beds of the soil developed when the gully bottom was occupied by ferns. As the percentage of pine pollen in PZ S-1 is approximately the same as in the surface samples from the modern treeless areas of the Bukovyna, pine groves were obviously rare. Scattered patches of mixed spruce-beach woods with some hornbeam and oak occurred at some distance from the gully. The corresponding time span might reflect the end of the Roman Warm Period (250 BC - 300 AD / 2.2-1.7 $\mathrm{ka} \mathrm{BP})$. In Ukraine, this warming is described in (Bezusko et al., 1988; Gerasimenko, 2007; Kalynovych, 2003, 2004). During subsequent phases, when the upper horizons of the lower soil were being formed, the colonisation of the area by ferns reached its maximum (PZ S-2 and S-3), broad-leaved taxa and pine in the vegetation cover decreased and spruce increased. The spread of clubmosses, coenotically connected with conifers, reached its maximum. Raised sphagnum bogs became abundant, a feature typical of cooling phases. This time span can be correlated with a cool phase between $1.7 \mathrm{ka}$ and $1.4 \mathrm{ka}$ BP (Bezusko et al., 1988). The intense humification of the lower soil, particularly of its Hk horizon, was caused by the absence of arboreal vegetation at the gully bottom. It also might have been controlled by some decrease in precipitation, followed by a decrease in run-off, less input of sand particles and a more stable surface. Calcium carbonates, intensely washed into the gully bottom, obviously arrived with the nutrients which strongly enriched the soils in Glomus-type fungi.

After $1.19 \mathrm{ka}$ BP $\left({ }^{14} \mathrm{C}\right.$ date), which marks the transition to the "Medieval Warm Period" (950$1250 \mathrm{AD} / 1.05-0.75 \mathrm{ka} \mathrm{BP}$ ), the spread of broadleaved taxa strongly increased. During the first half of the Medieval warming, represented at Sadgora 1 in the lower part of the PhkGL horizon in the middle soil, the gully slopes were covered by broad-leaved trees, while ferns continued to occupy its bottom (PZ S-4). Hornbeam dominated the woods, though oak, beach and lime also grew, as well as spruce, whose habitats were obviously located on north-facing slopes. The occurrence of walnut pollen indicates that, under the warm climate, the local population was able to cultivate this thermophillous tree near to their settlements. Later on, during formation of the upper part of the PhkGL horizon of the middle soil (and, particularly, its Hk horizon), woodlands became less dense, with well-developed undergrowth (hazel, buckthorn, elder) and a herbal ground cover. During the corresponding time span, there was the phase when spruce was dominant over hornbeam (PZ S-5), and then a phase with the opposite relationship of these taxa (PZ S-6). This alternation might reflect the climatic oscillations within the Medieval Warm Period described by (Bezusko et al., 1988) and (Mann et al., 2009), etc. Walnut disappeared when spruce reached its maximum extent. Domination of moisture-loving hornbeam and spruce indicates that the climate was humid. This wetter phase brought about a new input of gully alluvia, composed of brown-coloured material from the forest soils, which surrounded the locality. Ruderal plants, connected with eroding substrata (Chenopodiaceae, Artemisia, Lactuceae) appeared on slopes. 
At Ridkivtsi 1, the maximum spread of broad-leaved forest corresponds to the Eh horizon of the soil. During its formation, the site was located at the edge of hornbeam woodland with a small admixture of lime, oak and elm (PZ R-2). A few spruce and birch occurred on the northern slopes, but pine did not grow in the area. Hazel was common at the edge of broad-leaved wood, with a ground cover from diverse forbs and ferns. Sedges occurred at the bottom of the slope. Judging from the vegetational composition and ${ }^{14} \mathrm{C}$ date from the underlying beds, this time span should correspond to the Medieval Climatic Optimum, which was warmer and wetter than nowadays.

Both at Sadgora I (the $\mathrm{Pk}(\mathrm{h})(\mathrm{gl})$ horizon of the upper soil) and Ridkivtsi 1 (the lower part of the $\mathrm{H}(\mathrm{e})$ soil horizon), pronounced cooling is reflected in the drastic reduction of pollen of broad-leaved taxa. This corresponds well with the beginning of the Little Ice Age (XIV-XIX cent. / 750-150 yr $\mathrm{BP})$. On the other hand, the increase in ferns and microcharcoal particles, as well as the presence of Chamaenerion angustifolium pollen, might be connected with forest clearance. Conifers did not grow in the area at all. The Ridkivtsi I site was located in the open area, populated by very diverse forbs, grasses and ferns (PZ R-3). Patches of hornbeam, and a few lime and hazel, controlled weak eluviation in the soils. Some highly mesophytic plants (Valerianaceae, Lythraceae) and hygrophytes (reedmaces, sedges) grew at the bottom of the slope. The very low frequency of xerophytes and the maximum spread of ferns indicate that, in the studied area, the first half of this cool phase was not arid, the same as in the steppe belt of Ukraine (Gerasimenko, 2007). Later on, during formation of the upper part of $\mathrm{H}(\mathrm{e})$ horizon, herbs took the place of ferns (PZ R-4), with Lactuceae, Chenopodiaceae, Convolvulaceae, and Plantaginaceae being the most abundant. These plants, commonly regarded as synanthropic, indicate a direct human impact on the vegetation, obviously connected with the proximity of an ancient settlement. At the same time, the increase in grasses and appearance of typical steppe plants (Helianthemum, Rhamnus cathartica) could be evidence of an aridification trend, that is typical for the second half of the Little Ice Age, XVI-XIX cent. /400-150 yr BP (Bezusko et al., 1988; Gerasimenko, 2007). The intense spread of ferns (Chumak, 2012), or herbal and synanthropic vegetation (Gerasimenko, 2018; Huhmann et al., 2004), during the Late Subatlantic occurred across the whole area between the Carpathians and the Dniester valley.

At Sadgora 1, the period with the limited spread of broad-leaved trees, the Little Ice Age, corresponds to the $\mathrm{Pk}(\mathrm{h})(\mathrm{gl})$ and Hpk horizons of the upper soil, and was marked by the recurrent spread of ferns, the re-appearance of sphagnum peat bogs, and the reduction in herbal vegetation (PZ S-7). Judging from the fact that predominant pine pollen was transported by wind from a far distance, patches of conifers occupied only small areas locally, though heather and club-mosses, normally coenotically connected with conifers, occurred. Lime, hazel and buckthorn were infrequent. The predominance of ferns over herbs indicates a humid climate, though the position of the site in a gully and possible forest clearance should both be taken into the consideration. The noticeable appearance of pollen of mesophyllous broad-leaved taxa (hornbeam and beach) in the middle part of PZ S-6 might correspond to the short warm phase within the Little Ice Age (XV cent. / 600-500 yr BP) (Bezusko et al., 1980; Gerasimenko, 2007). Pollen of thermophilous walnut was absent in the area during the Little Ice Age.

The last phase of vegetational development is detected in the Hd horizons at Ridkivtsi 1 and the Ak horizon of the upper soil at Sadgora 1. Judging from the surface samples, at both sites the vegetation became rather similar to that in modern times. At Ridkivtsi 1, mesophytic steppe existed, with a very diverse herbal composition, though Lactuceae, Asteraceae and Chenopodiaceae slightly dominated over the other families (PZ R-4). Ferns became less abundant then earlier, and a role of arboreal vegetation increased. Patches of hornbeam woodland, with an admixture of lime, oak, elm and hazel, occurred. Spruce grew rarely, and pine was absent in the site vicinity. Walnut was extensively re-introduced near the settlements, and that clearly indicates a warm phase in recent centuries. At Sadgora 1, pollen percentages of trees show that they (particularly, pine) grew at a distance from the site. The closest woodland patches were formed by oak, lime and spruce. Walnut re-appeared near the settlements. Ferns decreased drastically, and herbal associations occupied the gully. Lactuceae and Chenopodiaceae dominated meadow-steppe coenoses, but Fabaceae became more common, which might point to the cultivation of pea family crops. The spread of mesophytic steppe instead of ferns can be explained by changes in agricultural land use - forest clearance was stopped, and ploughed land was turned into pasture. This is confirmed by the increase of spores of nutrientdemanding Glomus-type in this soil horizon.

Conclusions. Interpretation of pollen data based on the analysis of multiple modern surface pollen samples from the Bukovyna area is able to provide a history of vegetational change for the region. 
Changes in vegetation of the Subatlantic time, derived from the pollen record in the two soil profiles, reflect the climatic events that correspond well to the general trends over the last 2,000 years. Despite the fact that the two soil sections are located in different relief positions, and thus they have different soil genetic types, the derived pollen in the two sites clearly indicate the similar changes in vegetation over the period studied.

The phases of environmental development that occurred were as follows. 1. Patches of sprucebeach woodland on the plateau and abundant ferns in the gully. There was the end of the wet and warm Roman Warm Period, 2.2-1.7 ka BP. 2. The reduction in woodland (particularly broad-leaved taxa), the spread of herbal associations and ferns on plateau slopes, and ferns and club-mosses in the gully. There was an appearance of raised sphagnum peat bogs. This was the cool climate phase between 1.74 and 1.19 ka BP, the Dark Ages Cool Period; 2. The spread of broad-leaved woods (with Carpinus betulus as the dominant species), some increase in spruce and hazel distribution, and the introduction of thermophilous walnut. The reduction in ferns was compensated by an increase in diverse herbs in the ground cover of the forests. This was the warm climate phase after $1.19 \mathrm{ka} \mathrm{BP}$, the Medieval Warm Period; 3. A strong reduction in broad-leaved species (particularly oak), some increase in the distribution of spruce and pine, the re-appearance of raised peat bogs, and the suppression of walnut growth. This was the cool climate phase, the Little Ice Age, XIII-XIX cent. AD. 4. An increase in the distribution of broad-leaved trees (particularly hornbeam), the strong reduction in the spruce population and also of ferns, the disappearance of pine, and the spread of a mesophytic herbal association. The modern warm phase (the corresponding pollen spectra are similar to the surface samples).

In the thick soil succession at Sadgora 1, the pollen data provide the possibility of distinguishing the cooler sub-phase within the "Medieval warm period" and the warmer sub-phase within the "Little Ice Age", events which have their correlatives in palaeoclimatic records elsewhere.

Both sites, which have herbaceous cover at present, were covered by broad-leaved forest only during the "Medieval warm period". Ferns strongly predominated over herbal vegetation in the gully, and herbal or grass-herbal associations predominated over ferns on the plateau and its slopes (Ridkivtsi 1 site). At Sadgora 1, ferns also grew at the edges of the broad-leaved groves, framing the gully, and pine patches might occurred on eroded slopes of the gully, but pine never grew on the plateau during the studied time span.
The positions of both sites in the relief prevented their direct use for ancient by ancient agriculturalists, though, judging from the presence of walnut pollen in their deposits, the sites were located not far from the settlements. The increase in ferns and microcharcoal particles during the dry phases of the "Dark Age Period" and, particularly, of the "Little Ice Age", when pyrophitic herbs appeared, indicates the possibility of forest clearance. The spread of non-segetative synanthropic vegetation at the end of the "Little Ice Age" and the recent warm phase indicate that areas adjacent to the sites were used as pastures.

\section{References}

Artyushenko, A.T., Arap, R.Ya., Bezusko, L.G., 1982. Istoria rastitelnosti zapadnyh oblastei Ukrainy $\mathrm{v}$ chetvertichnom periode [Vegetation history of the western regions of Ukraine in the Quaternary]. Naukova dumka, Kiev (in Russian).

Barbarych, A.I. (Ed.), 1977. Geobotanichne rayonuvannya Ukrayuns'koyi RSR [Geobotanical zonation of Ukrainian SSR]. Naukova dumka, Kyiv (in Ukrainian).

Bezusko, L.G., Klimanov, V.A., Shelyag-Sosonko, Yu.R., 1988. Klimaticheskie uslovia Ukrainy v pozdnelednikovie i golotsene [Climatic conditions of Ukraine in the Late Glacial and Holocene]. In N. Hotinskiy (Ed.), Paleoklimaty golotsena Evropeyskoy chasti SSSR. Nauka, Moscow (in Russian).

Bolikhovskaya, N.S., 1995. Evolyutsia lessovopochvennoy formatsii Severo-Vostochnoy Yevrazii [Evolution of loess-soil formation of Northern Eurasia]. MGU, Moscow (in Russian).

Christiansen, B., Ljungqvist, F.C., 2012. The extratropical Northern Hemisphere temperature in the last two millennia: reconstructions of lowfrequency variability. Climate of the Past, 8, 765786.

Chumak, N., 2012. On vegetation dynamics in the foothills of the Eastern Carpathians during the Late Glacial and Holocene. Naukovyi visnyk Chernivetskogo universitetu. Geografia, 616, 5356.

Dmytruk, Yu.M., 2015. General description and characteristics of natural factors of pedogenesis. In Pedodiversity: Space and Time. Guidebook for the conference filed session. Chernivtsi National University, Chernivtsi.

Gerasimenko, N.P., 2007. Landshaftno-klimatychni zminy na terytorii Ukrainy za ostanni 2.5 tysiachi rokiv [Landscape and climatic changes on the territory of Ukraine over the last $2.5 \mathrm{ky}$. Istorychna heohrafia: pochatok XXI stolittia, 4153 (in Ukrainian).

Gerasimenko, N., Korzun, Yu., Ridush, B., 2014. Pryrodni zminy vprodovzh piznyolyodovykivya ta golotsenu u Serednyomu Pryprytti (za danymy palinologichnogo ta litologichnogo vyvchennya 
vidkladiv pechery Bukovynka, zal Sykhiy. [The Late Glacial and Holocene environmental changes in the Middle Prut Area (palaeontological and lithological data from the Bukovynka cave, the Sukhy Chamber)]. Fizychna geografia to geomorfologia, 74(2), 68-74 (in Ukrainian).

Gerasimenko, N., Ridush, B., Avdeyenko, Yu., 2018. Late Pleistocene and Holocene environmental changes recorded in deposits of the Bukovynka Cave (the East-Carpathian foreland, Ukraine). Quaternary International, In press. doi:10.1016/j.quaint.2018.03.028.

Grichuk, V.P., 1989. Istoria flory i rastitelnosti Russkoy ravniny $\mathrm{V}$ pleistotsene [History of flora and vegetation of the Russian Plain during the Pleistocene]. Nauka, Moscow (in Russian).

Huhmann, M., Kremenetski, K., Hiller, A., Brückner, H., 2004. Late Pleistocene landscape evolution on the upper Dnie ster valley, western Ukraine. Paleogeography, Paleoclimatology, Paleoecology, 209, 51-71. doi: 10.1016/j.palaeo.2004.02.014.

Kalynovych, N.O., 2003. Zminy lisovoho pokryvu Verkhniodnisterskoi rivnyny protiahom ostannikh 2,5 tysyach rokiv [Changes in the forest cover of the Upper Dniester Plain over the last $2.5 \mathrm{ky}$. Visnyk Lvivskogo natsionalnogo universytetu imeni I. Franka. Seria geografichna, 29, 184-190 (in Ukrainian).
Kalynovych, N., 2004. Holocene vegetation history of the Great Dnister Bogs region (Ukrainian Carpathian west-northern foreland). Acta Palaeobotanica, 44 (2), 167-173.

Kupriyanova, L.A., Alyeshina, L.A., 1972. Pyl'tsa i spory rasteniy flory Evropeyskoy chasti SSSR [Pollen and spores of plants of the European part of the USSR], Vol. 1. Nauka, Leningrad (in Russian).

Kupriyanova, L.A., Alyeshina, L.A., 1978. Pyl'tsa dvudol'nykh rasteniy flory Evropeyskoy chasti SSSR [Pollen of dicotyledons of the European part of the USSR], Vol. 2. Nauka, Leningrad (in Russian)

Mann, M. E., Zhang Z., Rutherford, S., Bradley, R., Hughes, M., Shindell, D., Ammann, C., Faluvegi, G., Ni, F., 2009. Global Signatures and Dynamical Origins of the Little Ice Age and Medieval Climate Anomaly. Science, 326 (5957), 1256-60. doi: 10.1126/science.1177303.

Reille, M., 1995. Pollen et spores d'Europe et d'Afrique du Nord. Supplement 1. Laboratoire de Botanique Historique et Palynologie. URA CNRS 1152, Marseille.

Reille, M., 1998. Pollen et spores d'Europe et d'Afrique du Nord. Supplement 2. Laboratoire de Botanique historique et Palynologie. URA CNRS 1152, Marseille. 